Tropical Journal of Pharmaceutical Research June 2017; 16 (6): 1285-1292

ISSN: $1596-5996$ (print); 1596-9827 (electronic)

(C) Pharmacotherapy Group, Faculty of Pharmacy, University of Benin, Benin City, 300001 Nigeria.

All rights reserved.

Available online at http://www.tjpr.org

Original Research Article

http://dx.doi.org/10.4314/tjpr.v16i6.11

\title{
Okra (Abelmoschus esculentus Linn) inhibits lipopolysaccharide-induced inflammatory mediators in BV2 microglial cells
}

\author{
Nootchanat Mairuae ${ }^{1 *}$, Poonlarp Cheepsunthorn ${ }^{2}$, Chalisa Louicharoen \\ Cheepsunthorn $^{2}$, and Walaiporn Tongjaroenbuangam ${ }^{1}$ \\ ${ }^{1}$ Faculty of Medicine, Chulalongkorn University, Bangkok 10330, ${ }^{2}$ Faculty of Medicine, Mahasarakham University, Maha \\ Sarakham 44000, Thailand
}

*For correspondence: Email: mairuae.n@gmail.com; Tel: 6643-712-992; Fax: 6643-712252-991

\begin{abstract}
Purpose: To investigate the inhibitory effects of okra (Abelmoschus esculentus Linn.) extract on the production of reactive oxygen species (ROS) and pro-inflammatory cytokines in lipopolysaccharide (LPS)-stimulated BV2 microglia.

Methods: Okra was extracted with ethanol by Soxhlet extraction. Non-cytotoxic doses of okra at concentrations of 50, 100 and $200 \mu \mathrm{g} / \mathrm{mL}$ were used in this study. BV2 cells were cultured and treated with LPS in the presence or absence of okra at the concentrations indicated above. ROS, nitric oxide

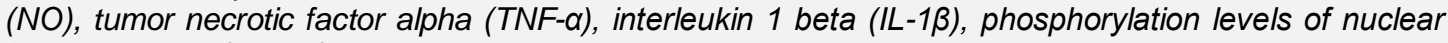
factor-kappa B (NF-kB) p65 and Akt were determined.

Results: Treatment of BV2 cells with okra concentrations of 50, 100 and $200 \mu \mathrm{g} / \mathrm{mL}$ significantly suppressed LPS-induced NO as well as ROS compared to untreated cells. There was also a significant decrease in the production of TNF- $\alpha$ and IL-1 $\beta$ in okra-treated BV2 microglia cells. The level of LPSinduced NF-kB p65 phosphorylation was significantly decreased by okra treatment. In addition, okra inhibited LPS-induced Akt phosphorylation, which is an upstream molecule of NF-kB.

Conclusion: Okra exerts anti-oxidative and anti-inflammatory effects in LPS-stimulated BV2 microglial cells by suppressing Akt-mediated NF-KB pathway. This suggests that okra might be a valuable agent for the treatment of anti-neuroinflammatory diseases mediated by microglial cells.
\end{abstract}

Keywords: Abelmoschus esculentus Linn, Inflammatory cytokines, Lipopolysaccharide, Neuroinflammation, Microglia, Reactive oxygen species

Tropical Journal of Pharmaceutical Research is indexed by Science Citation Index (SciSearch), Scopus, International Pharmaceutical Abstract, Chemical Abstracts, Embase, Index Copernicus, EBSCO, African Index Medicus, JournalSeek, Journal Citation Reports/Science Edition, Directory of Open Access Journals (DOAJ), African Journal Online, Bioline International, Open-J-Gate and Pharmacy Abstracts

\section{INTRODUCTION}

Microglia, the resident immune cells located in the central nervous tissue (CNS), play an important role in CNS homeostasis during development, adulthood and ageing. In their resting state, they vigilantly monitor the health of neurons. In the event of brain damage or infection, microglia are activated, migrate to the site of injury, proliferate and phagocytose cells and cellular compartments. However, overactivation of microglia could contribute to neuronal cell death as seen in many neurodegenerative diseases [1] due to the secretion of inflammatory mediators and neurotoxic factors such as nitric oxide (NO), interleukin 1 beta (IL-1 $\beta$ ), tumor necrotic factor alpha $(T N F-\alpha)$, and reactive oxygen species (ROS) $[2,3]$. 
One transcription factor that plays a significant role in the inflammatory response of activated microglia is the inducible nuclear factor-kappa $B$ (NF-kB) [4]. NF-kB exists in the cytoplasm in an inactive form associated with regulatory proteins called inhibitors of kB (lkB). Inducible NF-kB activation depends on phosphorylation-induced proteosomal degradation of the inhibitor of IKBs, resulting in the nuclear translocation of NF- $\mathrm{KB}$. The transcription activity of $\mathrm{NF}-\kappa \mathrm{B}$ can be regulated by several kinases, including $\mathrm{PI} 3 \mathrm{~K} / \mathrm{Akt}$ and ERK signaling pathways [5]. Therefore, chemical compounds that can inhibit microglial activation through NF-kB/PI3K/Akt/ERK signaling pathways will result in neuroprotection.

Okra, Abelmoschus esculentus (L.) Monech (also known as gumbo or lady's finger), belongs to the family Malvaceae. It plays an important role in the human diet, supplying many nutrients. Okra seeds are rich in various flavonoids including oligomeric catechins, quercetin, and rutin. Previous studies reported that okra possesses hepatoprotective [6], antidiabetic and anticancer [7] activities. In addition, it has been reported that okra treatment reverses cognitive deficits and protect against morphological changes in the CA3 region of dexamethasone-treated mice [8]. Okra extract and its bioactive constituents, quercetin and rutin, also protect neuronal function and improve learning and memory deficits in dexamethasone-treated mice [9]. Recently, we demonstrated that okra treatment decreases ROS and $\mathrm{H}_{2} \mathrm{O}_{2}$ production, tau phosphorylation, and cellular events associated with $A D$ in a stably expressed HFE neuroblastoma SH-SY5Y cell line [10]. However, the role of okra in microglial activation has not yet been studied. In this study, the effects of okra extract on oxidative and inflammatory responses in LPS-induced stimulation of murine BV2 microglial cells was determined.

\section{EXPERIMENTAL}

\section{Materials}

All the cell culture reagents were purchased from Hyclone (South Logan, UT). LPS was purchased from Sigma (St. Louis, MO). The BCA protein assay kit was obtained from Pierce (Rockford, IL, USA), IL- $1 \beta$ and TNF- $\alpha$ ELISA kits were purchased from Cell Biolab (San Diego, CA), and the ROS detection kit was purchased from Calbiochem (La Jolla, CA). The Griess reagent kit for nitrite determination was purchased from Molecular Probes (Eugene, OR). NF-kB p65, pNF-kB p65, Akt and phosphor-Akt antibody were purchased from Santa Cruz Biotechnology (Santa Cruz, CA, USA).

\section{Collection and preparation of okra extract}

Okra fruits were collected in January 2014 at Maha Sarakham Province, Thailand and identified by using the Taxonomic literature (Flora of China) [11]. A voucher specimen (no. MSUT-6736) was deposited at MSUT (Mahasakham University Thailand). Okra extraction was carried out according to a previously reported method [8]. Briefly, okra was dried at $60^{\circ} \mathrm{C}$ for $24 \mathrm{~h}$ in a hot air oven. Dried okra was ground in a blender and subjected to Soxhlet extraction using ethanol as the solvent. Fifty grams of okra and $200 \mathrm{ml}$ of ethanol were used in the extraction. Triplicate extractions were performed. The solvent was vacuum-distilled at $60{ }^{\circ} \mathrm{C}$ in a rotary evaporator and the remaining extract was dried at room temperature for several days to ensure the removal of any residual solvent.

\section{Cell culture}

Murine BV2 microglial cell line was cultured in 75 $\mathrm{cm}^{2}$ flasks with DMEM supplemented with $5 \%$ FBS containing 100 units $/ \mathrm{mL}$ penicillin and 100 $\mu \mathrm{g} / \mathrm{mL}$ streptomycin, and maintained in a $5 \%$ $\mathrm{CO}_{2}$ incubator at $37^{\circ} \mathrm{C}$. In assays of cell viability, NO levels and ROS levels, BV2 cells were plated at a density of $1 \times 10^{4}$ cells/well in 96 well-plates. In assays seeking to determine TNF$\alpha$ and IL-1 $\beta$ production, BV2 cells were plated at density of $1 \times 10^{5}$ cells/well in 24 well-plates. To determine Akt, p-Akt, NF-KB p65 and phosphor NF-kB p65 levels, cells were plated at a density 1 $\times 10^{6}$ cells/well in 6 well-plates. Cells were cultured as described above and incubated for $24 \mathrm{~h}$. At the start of each experiment, the growth medium in each well was completely removed and replaced with medium containing LPS with or without the specified concentrations of okra extract $(50,100,200 \mu \mathrm{g} / \mathrm{mL})$ or quercetin (12 $\mu \mathrm{M})$ in serum-free medium.

\section{Cell viability assay}

MTT (3-(4, 5-dimethylthiazol-2-yl)-2, 5diphenyltetrazolium bromide, Sigma-Aldrich, St. Louis, MO) assay was used to quantify cell viability and cytotoxicity. After $24 \mathrm{~h}$ of treatment, medium was removed from each well and replaced with $0.1 \mathrm{~mL}$ of MTT reagent (0.5 $\mathrm{mg} / \mathrm{mL}$ ) in serum free DMEM. Cells were incubated for $2 \mathrm{~h}$ at $37^{\circ} \mathrm{C}$. After $2 \mathrm{~h}$ of treatment, MTT reagent was removed, the formazan dye was dissolved with DMSO, and absorption was read at $570 \mathrm{~nm}$ using a Synergy-4 plate reader (BioTek Instruments, Inc., Fisher Scientific, St. Louis, MO). 


\section{Nitric oxide assay}

After $24 \mathrm{~h}$ of treatment, the level of $\mathrm{NO}$ in the supernatant was estimated with Griess reagent according to the manufacturer's protocol.

\section{Determination of intracellular reactive oxygen species}

Cells were seeded in 96-well plates and cultured as described above. After $24 \mathrm{~h}$, the cells were incubated with $10 \mu \mathrm{M}$ CM-H2DCFDA for $30 \mathrm{~min}$ at $37{ }^{\circ} \mathrm{C}$ in a $\mathrm{CO}_{2}$ incubator. Then, cells were washed with PBS and treated with LPS in the presence or absence of okra extracts or quercetin in serum-free medium for $24 \mathrm{~h}$. The fluorescence intensity of DCF was measured at $488 \mathrm{~nm}$ excitation and $520 \mathrm{~nm}$ emission on a Synergy HT Multi-Mode microplate reader (BioTek instruments, Winooski, VT).

\section{Enzyme linked immunosorbent assay (ELISA)}

Cells in 24 well-plates were treated as described above. After $24 \mathrm{~h}$ of treatment, the levels of IL-1 $\beta$ and TNF- $\alpha$ in supernatants were quantified using ELISA kits according to the manufacturer's protocol.

\section{Western blot analysis}

After treatment, whole cell protein lysates were prepared in a lysis buffer. The total protein concentrations in samples were determined (Pierce, Rockford, IL, USA). The total protein from each sample was separated by $10 \%$ SDSPAGE and transferred to a nitrocellulose (NC) membrane (Bedford, MA, USA). Also, the membranes were blocked in $5 \%$ BSA and $0.1 \%$ Tween-20 at room temperature for $1 \mathrm{~h}$ and incubated overnight at $4{ }^{\circ} \mathrm{C}$ with antibodies against Akt, p-Akt, NF-kB p65, phosphor NF-kB

(A)

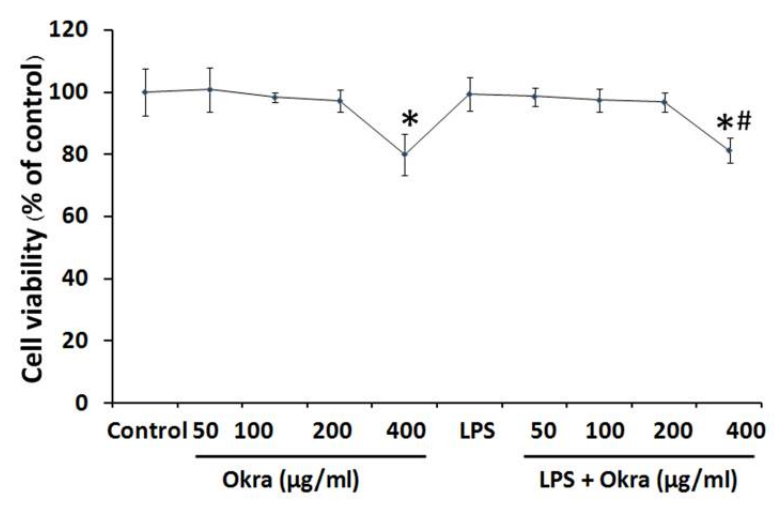

p65 and $\beta$-actin. The blots were washed thrice and incubated with secondary antibody coupled to horseradish peroxidase. The protein bands were detected using Supersignal West Pico chemiluminescence (Pierce, Rockford, IL, USA).

\section{Statistical analysis}

All the data are expressed as mean \pm SEM at three independent experiments performed in triplicate (9 replicates for each value). Multiple comparison of data was carried out by one-way ANOVA followed by Bonferroni post-tests. $P<$ 0.05 was considered statistically significant.

\section{RESULTS}

\section{Effect of okra and quercetin on cell viability of BV2 cells}

MTT assay was used to determine the cytotoxicity of okra and quercetin on BV2 cells. The results show that, at concentrations up to $200 \mu \mathrm{g} / \mathrm{mL}$ of Okra and $12 \mu \mathrm{M}$ of quercetin, neither okra nor quercetin exhibited toxicity against BV2 cells (Figure 1A and Figure 1B). Therefore, non-cytotoxic doses of okra $(50,100$ and $200 \mu \mathrm{g} / \mathrm{mL}$ ) and quercetin (6 and $12 \mu \mathrm{M}$ ) were used in this study.

\section{Effect of okra and quercetin on LPS-induced NO production}

In order to investigate the role of okra as an antiinflammatory mediator, the effects of okra on LPS-induced NO production were examined. After $24 \mathrm{~h}$ of treatment with okra, NO production slightly decreased compared to the untreated cells (Figure 2A). After the treatment with LPS, NO production was significantly elevated

(B)

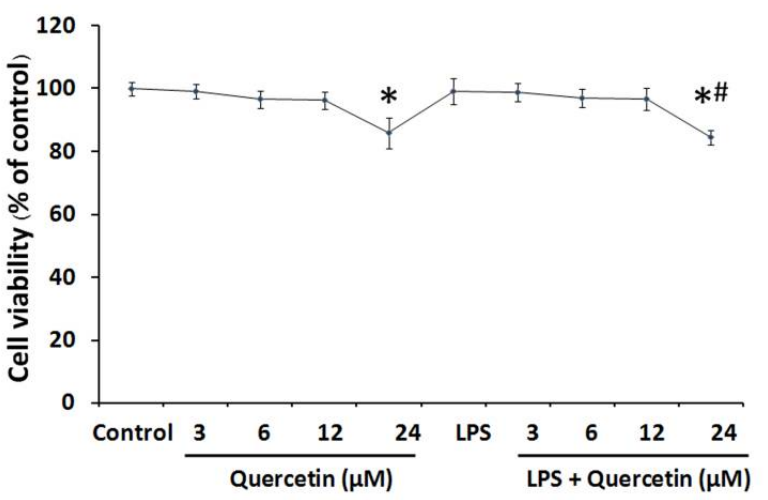

Figure 1: Effect of okra (A) and quercetin (B) on the viability of BV2 microglial cells. Data represent mean \pm SEM $(\mathrm{n}=3) ;{ }^{*} p<0.05$ when compared with control group; $\# p<0.05$ when compared with LPS-treated group 
compared to untreated cells. However, okra treatment significantly decreased LPS-induced $\mathrm{NO}$ production in a concentration-dependent manner (50, 100 and $200 \mu \mathrm{g} / \mathrm{mL}$.) Since quercetin is a constituent of okra and has been reported to decrease $\mathrm{NO}$ in various models, we investigated the effect of this compound also. As with okra, treatment with quercetin significantly reduced the level of $\mathrm{NO}$ in a concentrationdependent manner (Figure 2B), returning the elevated NO level to that seen in control cells.

\section{Effect of okra and quercetin on ROS production}

The antioxidant effect of okra on activated microglia was investigated by measuring ROS production. After $24 \mathrm{~h}$ treatment with okra, ROS level significantly decreased compared to untreated cells. After the treatment with LPS, the ROS level was significantly increased compared to untreated cells. When cells were treated with okra in the presence of LPS, there was a concentration-dependent attenuation in ROS

(A)

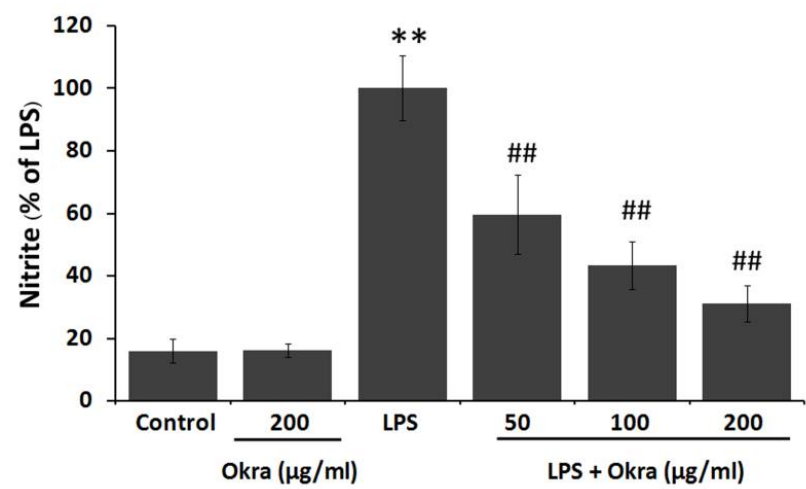

production (Figure 3A). The ROS level also decreased significantly after treatment with quercetin compared with the untreated control group. Furthermore, in cells stimulated with LPS, quercetin treatment attenuated LPS-induced ROS production in a concentration-dependent manner (Figure 3B).

\section{Effect of okra and quercetin on LPS-induced TNF- $\alpha$ and IL-1 $\beta$ production}

To analyze the anti-inflammatory properties of okra on LPS-stimulated BV2 microglial cells, production of TNF- $\alpha$ and IL-1 $\beta$ in the cell culture media was measured by ELISA. The results showed that TNF- $\alpha$ and IL-1 $\beta$ production increased significantly after LPS treatment.

Treatment with okra suppressed LPS-induced TNF- $\alpha$ and IL-1 $\beta$ production (Figure 4A) in a concentration-dependent manner. Quercetin treatment also attenuated LPS-induced TNF- $\alpha$ and IL-1 $\beta$ production, again in a concentrationdependent manner (Figure 4B).

(B)

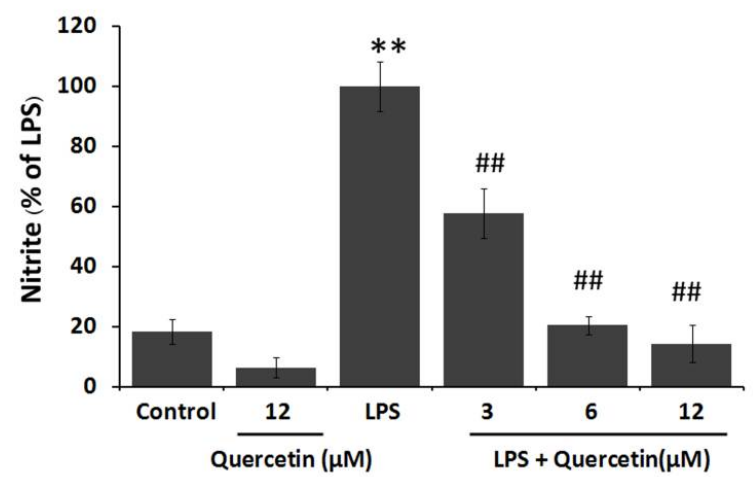

Figure 2: Effect of okra (A) and quercetin (B) on NO production induced by LPS in BV2 microglial cells. Data represent the mean \pm SEM $(\mathrm{n}=3) ;{ }^{*} p<0.05$ when compared with control group; ${ }^{* *} p<0.01$ when compared with control group; $\# p<0.01$ when compared with LPS-treated group; $\# p<0.05$ when compared with LPS-treated group

(A)

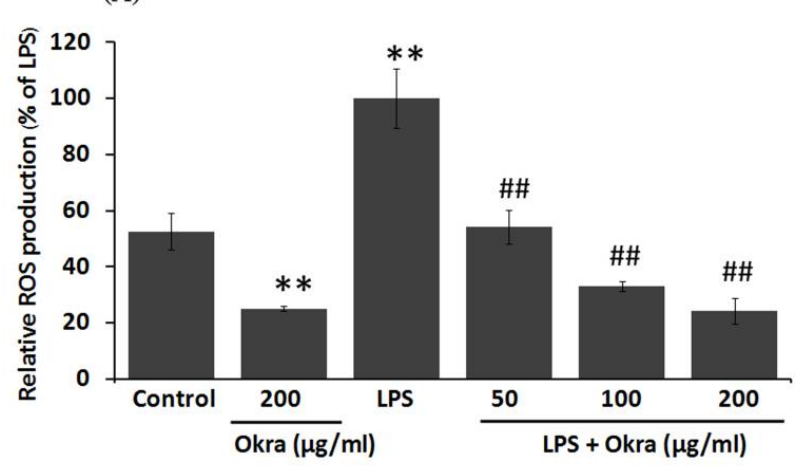

(B)

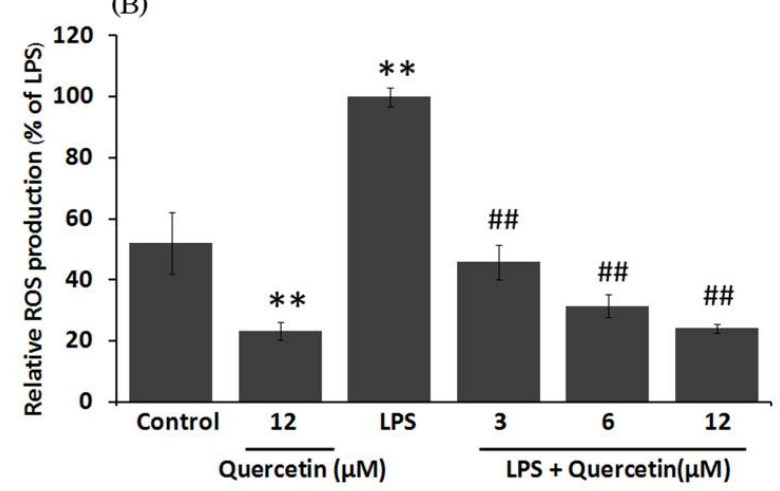

Figure 3: Effect of okra (A) and quercetin (B) on ROS production induced by LPS in BV2 microglial cells. The data represent the means \pm SEM $(n=3)$; ${ }^{*} p<0.05$ when compared with control group; ${ }^{* *} p<0.01$ when compared with control group; \#p<0.01 when compared with LPS-treated group; \#p<0.05 when compared with LPStreated group 


\section{Effect of okra and quercetin on LPS-induced NF-KB activation}

The results showed that LPS significantly increased the phosphorylation of NF-kBp65 compared with the untreated cells. However, treatment with okra suppressed LPS-induced NF- $\mathrm{B}$ p65 phosphorylation (Figure 5). As with the okra treatment, quercetin significantly attenuated LPS-induced NF-кB p65 phosphorylation (Figure 5).

\section{Effect of okra and quercetin on LPS-induced Akt phosphorylation}

High levels of Akt phosphorylation were observed in LPS-treated cells. However, treatment with either okra or quercetin

(A)

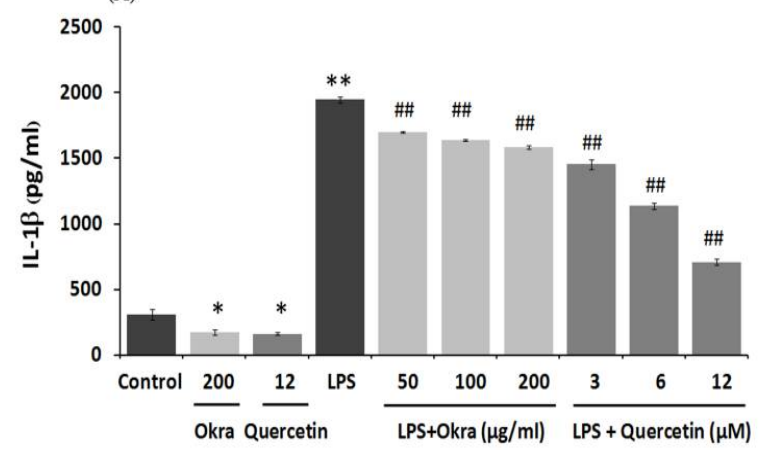

significantly inhibited LPS-induced Akt phosphorylation during LPS-induced microglia activation (Figure 6).

\section{DISCUSSION}

Neuroinflammation mediated by microglia has been implicated in the development of neurodegenerative diseases [12]. Treatments that inhibit microglial activation may therefore be effective in treating neurodegenerative diseases. $\mathrm{NO}$ is a major microglia-derived inflammatory mediator, and high levels of this mediator are reported to be involved in the onset of neurodegenerative diseases such as PD, AD, and multiple sclerosis [13]. NO can be converted to a number of more reactive derivatives known

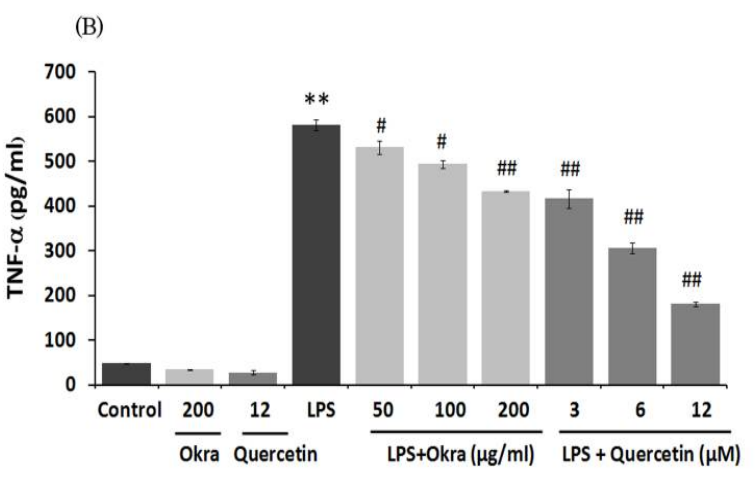

Figure 4: Effect of okra and quercetin on LPS-induced IL-1 $\beta$ and TNF- $\alpha$ production. After $24 \mathrm{~h}$ of treatment, culture media were collected for determination of IL-1 $\beta(A)$ and TNF- $\alpha(B)$ production using the ELISA kits. Data represent mean \pm SEM $(\mathrm{n}=3) ;{ }^{*} p<0.05$ when compared with control group; ${ }^{* *} p<0.01$ when compared with control group; $\# p<0.05$ when compared with LPS-treated group; \#\# $<0.01$ when compared with LPS-treated group

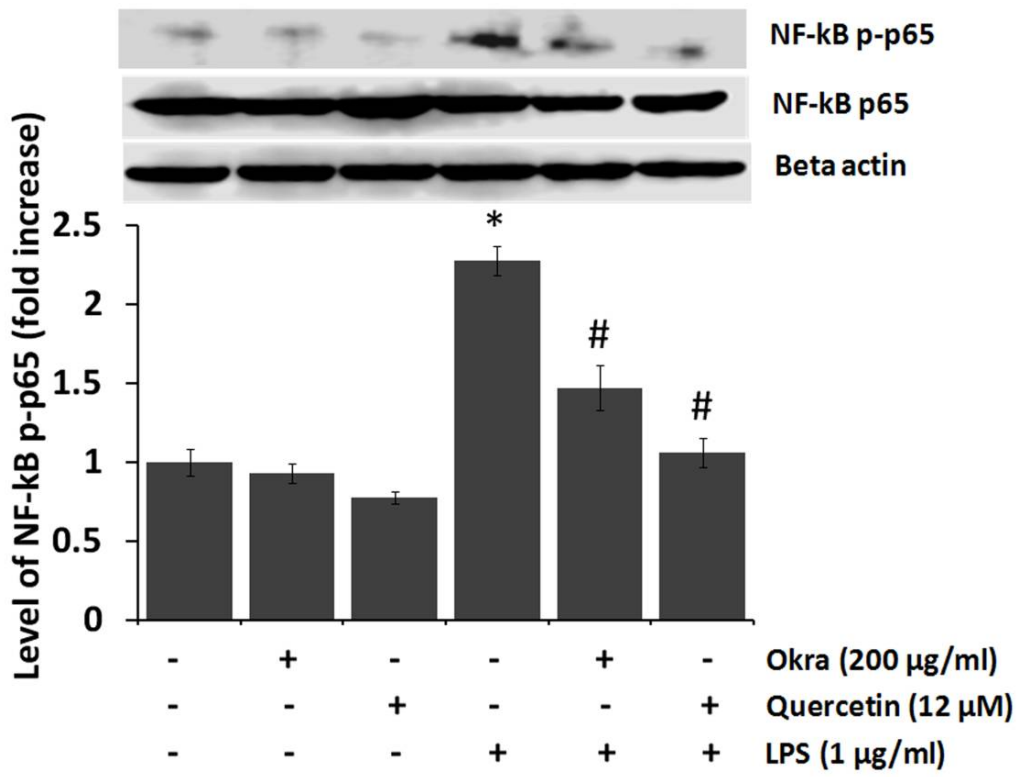

Figure 5: Effects of okra and quercetin on LPS-induced NF-kB activation. After $24 \mathrm{~h}$ of treatment, total cells lysates were collected and levels of anti-p65 and phospho p65 were detected by western blot assay. Levels of NF-kB p-p65 were normalized to beta actin. Histograms represent the fold-increase of NF-kB p-p65 relative to that of the untreated control. Data represent mean $\pm \operatorname{SEM}(n=3) ;{ }^{*} p<0.05$ when compared 


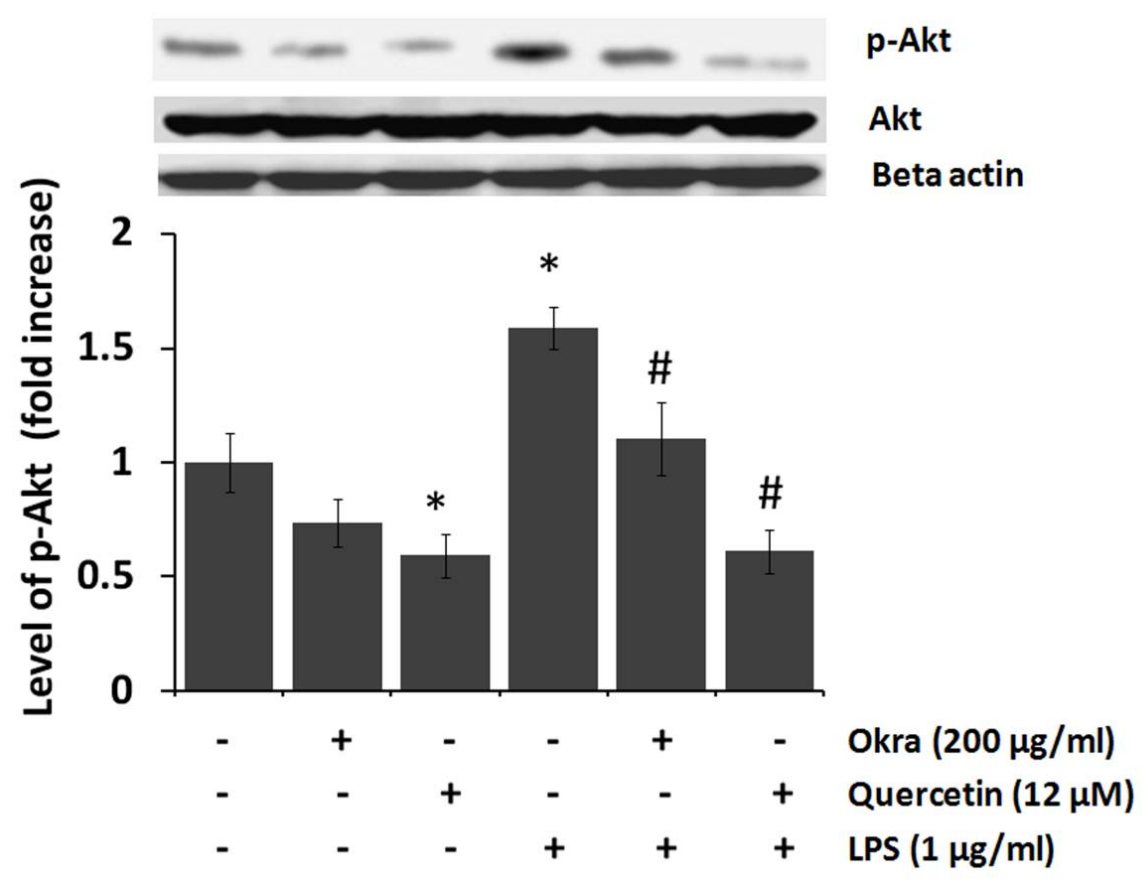

Figure 6: Effect of okra and quercetin on LPS-induced Akt phosphorylation. After $24 \mathrm{~h}$ of treatment, Total cell lysate was collected and levels of anti-Akt and phospho Akt determined by western blot assay. Levels of p-Akt were normalized to beta actin. Histograms represent the fold-increase of $p$-Akt relative to that of the untreated control. These data represent mean \pm SEM $(\mathrm{n}=3) ;{ }^{*} p<0.05$ when compared with control group; ${ }^{* *} p<0.01$ when compared with control group; \#p<0.01 when compared with LPS-treated group; \#p<0.05 when compared with LPS-treated group

as reactive nitrogen species (RNS) such as peroxynitrite $\mathrm{NO}_{2}, \mathrm{~N}_{2} \mathrm{O}_{3}$, and S-nitrosothiols. These RNS induce cell death, in part, by inhibiting mitochondrial respiration or activation of mitochondrial permeability transition, triggering neuronal apoptosis or necrosis. [14]. In addition, high levels of NO/RNS-induced respiratory inhibition result in glutamate release, and subsequent excitotoxic death of neuron [15]. ROS are highly reactive molecules. Excessive production of ROS during environmental stress can damage cell structures by causing oxidation of proteins, peroxidation of lipids, and damage to nucleic acids, ultimately leading to cell death [16]. In addition, ROS also play a critical role in enhancing neuroinflammation through the activation of redox-sensitive transcriptional factors such as NF-kB, resulting in increases in the synthesis of the proinflammatory genes IL-1 and TNF- $\alpha$ which in turn, exacerbates the pathologic process in inflammatory CNS diseases [17]. Medicinal plants possessing both NO- and ROS-inhibitory activities might therefore be good candidates for the treatment of neuroinflammatory disease. In this study, we demonstrated that okra inhibit LPS-induced NO production in a concentration-dependent manner. Since quercetin is a major constituent of okra and has been reported to have antioxidant and anti-inflammatory activities, quercetin was included as a positive control in this study. The results showed that quercetin treatment significantly attenuate LPS-induced NO production in a concentration-dependent manner. This result is consistent with reports that quercetin inhibits LPS-induced NO production in BV2 microglial cells [18] as well as in other cellular models [19]. The results also demonstrated that okra and quercetin treatment dramatically decrease LPS-induced ROS levels in a concentration-dependent manner. It has been reported that quercetin is a major constituent of okra that exerts potent antioxidant activity in different pathway, including direct quenching of ROS, chelation of metal ions and inhibition of the activity of oxidases, results suggest the ability of okra extract to reduce ROS in BV2 cells might be due to the presence of this compound.

Inflammatory cytokines such as TNF- $\alpha$ and IL-1 $\beta$ also play an important role in the pathogenesis of neurodegenerative disorders [20]. Elevated TNF$\alpha$ and IL-1 $\beta$ can be considered to be a histopathological hallmark of neurological diseases [21]. It has been reported that TNF- $\alpha$ receptors are widely expressed in the CNS, and TNF family ligands are the main inducers of apoptosis in the CNS. Therefore, high levels of TNF- $\alpha$ secreted by activated microglia during 
chronic inflammation may contribute to neuronal cell death through the apoptotic pathway [22]. In this study, it was demonstrated that okra inhibited LPS-induced TNF- $\alpha$ and IL-1 $\beta$ production, suggesting that okra has an antiinflammatory effect on LPS-activated BV2 microglial cells. The result also demonstrated that quercetin treatment significantly reduced LPS-induced TNF- $\alpha$ and IL-1 $\beta$ production. This result is consistent with reports that quercetin lowered levels of IL-1 $\beta$ as well as TNF- $\alpha$ in rat adjuvant arthritis and in blood mononuclear cells, respectively [23]. These results suggest that okra might be a good candidate for suppressing inflammatory mediators in neuroinflammatory disease.

NF-KB is a transcription factor that plays a critical role in regulating inflammatory mediators and inflammatory cytokines [4]. Normally, NF-KB proteins are present in the cytoplasm in association with members of the IKB family of inhibitory proteins [24]. After stimulation with LPS, NF-KB is activated by phosphorylation, leading to increased nuclear translocation and the DNA-binding activity of NF-KB in its specific promoter regions, resulting in the expression of proinflammatory genes. Therefore, inhibition of NF-KB activation represents a potential therapeutic strategy for neuroinflamatory diseases by inhibiting proinflammatory cytokine production. In this study, we examined the effect of okra on LPS-induced NF-KB activation by determining levels of phosphorylated NF-KB p65. The results showed that okra inhibited LPSinduced NF-KB activation, based on decreasing levels of phosphorylated NF-KB p65.

However, okra could not completely inhibit NF-KB activation, suggesting that other transcription factors such as AP- 1 and CREB may also be involved in LPS-mediated transcriptional induction. It was also demonstrated that quercetin treatment significantly inhibited NF-KB activation. This correlates with the finding that quercetin treatment inhibits LPS-induced NO production in BV2 microglial cells by suppressing the NF-kB pathway [25]. A recent study showed that LPS-induced NF-KB activation is directly regulated by phosphorylation of PI3K/Akt in microglial cells [4], so we further investigated the effect of okra on LPS-induced Akt phosphorylation. These results show that okra significantly reduce LPS-induced Akt phosphorylation, suggesting that okra-induced decreases in production of the inflammatory mediator NO, and proinflammatory cytokines TNF- $\alpha$ and IL- $1 \beta$ are due, at least in part, to inhibition of the Akt/NF-KB signaling pathway.

\section{CONCLUSION}

The findings of this study demonstrate that okra attenuates the production of the proinflammatory mediators, NO and ROS, as well as production of TNF- $\alpha$ and IL-1 $\beta$, in LPS-stimulated BV2 microglial cells by suppressing Akt-mediated NF$\mathrm{KB}$ pathway. The findings provide evidence that okra possesses potential anti-oxidative and antiinflammatory activities in neuronal disorders induced by activated microglia.

\section{DECLARATIONS}

\section{Acknowledgement}

This research was supported by grants from the Faculty of Medicine and the Division of Research Facilitation and Dissemination at Mahasarakham University. The authors would like to thank Assist. Prof. Dr. Wannachi Chatan, who made herbarium specimens and $\mathrm{Dr}$ Tim Cushnie for language-editing assistance.

\section{Conflict of Interest}

No conflict of interest associated with this work.

\section{Contribution of Authors}

The authors declare that this work was done by the authors named in this article and all liabilities pertaining to claims relating to the content of this article will be borne by them.

\section{Open Access}

This is an Open Access article that uses a funding model which does not charge readers or their institutions for access and distributed under the terms of the Creative Commons Attribution License (http://creativecommons.org/licenses/by/ 4.0) and the Budapest Open Access Initiative (http://www.budapestopenaccessinitiative.org/rea d), which permit unrestricted use, distribution, and reproduction in any medium, provided the original work is properly credited.

\section{REFERENCES}

1. Rogers J, Mastroeni D, Leonard B, Joyce J, Grover A. Neuroinflammation in Alzheimer's disease and Parkinson's disease: are microglia pathogenic in either disorder? Int. Rev. Neurobiol, 2007; 82: 235-246

2. Boje KM, Arora PK. Microglial-produced nitric oxide and reactive nitrogen oxides mediate neuronal cell death. Brain Res, 1992; 587(2): 250-256. 
3. Chao CC, Hu S, Peterson PK. Glia, cytokines, and neurotoxicity. Crit Rev Neurobiol, 1995; 9(2-3): 189-205.

4. Tak PP, Firestein GS. NF-kappaB: a key role in inflammatory diseases. J Clin Invest, 2001; 107(1): 7-11.

5. Saponaro C, Cianciulli $A$, Calvello $R$, Dragone $T$, lacobazzi F, Panaro MA. The PIJK/Akt pathway is required for LPS activation of microglial cells. Immunopharmacol Immunotoxicol, 2012; 34(5): 858865.

6. Kochunov P, Thompson PM, Lancaster JL, Bartzokis G, Smith S, Coyle T, Royall DR, Laird A, Fox PT. Relationship between white matter fractional anisotropy and other indices of cerebral health in normal aging: tract-based spatial statistics study of aging. Neuroimage, 2007; 35(2): 478-487.

7. Sabitha $V$, Ramachandran $S$, Naveen $K R$, Panneerselvam K. Antidiabetic and antihyperlipidemic potential of Abelmoschus esculentus (L.) Moench. in streptozotocin-induced diabetic rats. J Pharm Bioallied Sci, 2011 3(3): 397-402.

8. Tongjaroenbuangam $W$, Ruksee $N$, Chantiratikul $P$, Pakdeenarong $N$, Kongbuntad $W$, Govitrapong $P$. Neuroprotective effects of quercetin, rutin and okra (Abelmoschus esculentus Linn.) in dexamethasonetreated mice. Neurochem Int, 2011; 59(5): 677-685.

9. Mathew M, Subramanian S. In vitro screening for anticholinesterase and antioxidant activity of methanolic extracts of ayurvedic medicinal plants used for cognitive disorders. PLoS One, 2014; 9(1): e86804.

10. Mairuae N, Connor JR, Lee SY, Cheepsunthorn $P$, Tongjaroenbuangam $W$. The effects of okra (Abelmoschus esculentus Linn.) on the cellular events associated with Alzheimer's disease in a stably expressed HFE neuroblastoma SH-SY5Y cell line. Neurosci Lett, 2015; 603: 6-11.

11. Flora of China. Abelmoschus esculentus (Linnaeus) Moench, Methodus. 1: 617. 1794. [cited 2017 April 6]. Available from: http://www.efloras.org/florataxon.aspx?flora_id=2\&taxon $i d=200013666$

12. Liu B, Hong JS. Role of microglia in inflammationmediated neurodegenerative diseases: mechanisms and strategies for therapeutic intervention. J Pharmacol Exp Ther, 2003; 304(1): 1-7.

13. MacMicking J, Xie QW, Nathan C. Nitric oxide and macrophage function. Annu Rev Immunol, 1997; 15: 323-350.

14. Brown GC, Cooper CE. Nanomolar concentrations of nitric oxide reversibly inhibit synaptosomal respiration by competing with oxygen at cytochrome oxidase. FEBS Lett, 1994; 356(2-3): 295-298
15. Stewart VC, Heslegrave AJ, Brown GC, Clark JB, Heales SJ. Nitric oxide-dependent damage to neuronal mitochondria involves the NMDA receptor. Eur $J$ Neurosci, 2002; 15(3): 458-464.

16. Mittler R. Oxidative stress, antioxidants and stress tolerance. Trends Plant Sci, 2002; 7(9): 405-410.

17. Chabrier PE, Demerle-Pallardy C, Auguet M. Nitric oxide synthases: targets for therapeutic strategies in neurological diseases. Cell Mol Life Sci, 1999; 55(8-9): 1029-1035.

18. Simonyi A, Chen Z, Jiang J, Zong Y, Chuang DY, Gu Z, Lu CH, Fritsche KL, Greenlief CM, Rottinghaus GE, et al. Inhibition of microglial activation by elderberry extracts and its phenolic components. Life Sci, 2015; 128: $30-38$

19. Yang WS, Jeong $D$, Yi YS, Lee BH, Kim TW, Htwe KM, Kim YD, Yoon KD, Hong S, Lee WS, et al. Myrsine seguinii ethanolic extract and its active component quercetin inhibit macrophage activation and peritonitis induced by LPS by targeting to Syk/Src/IRAK-1. J Ethnopharmacol, 2014; 151(3): 1165-1174.

20. Jiao J, Xue B, Zhang L, Gong Y, Li K, Wang $H$, Jing $L$, Xie J, Wang $X$. Triptolide inhibits amyloid-beta1-42induced TNF-alpha and IL-1beta production in cultured rat microglia. J Neuroimmunol, 2008; 205(1-2): 32-36.

21. Dheen ST, Kaur C, Ling EA. Microglial activation and its implications in the brain diseases. Curr Med Chem, 2007; 14(11): 1189-1197.

22. Alvarez S, Blanco A, Fresno M, Munoz-Fernandez M. A. TNF-alpha contributes to caspase-3 independent apoptosis in neuroblastoma cells: role of NFAT. PLOS One, 2011; 6(1): e16100.

23. Gardi $C$, Bauerova K, Stringa B, Kuncirova V, Slovak $L$, Ponist S, Drafi F, Bezakova L, Tedesco I, Acquaviva A, et al. Quercetin reduced inflammation and increased antioxidant defense in rat adjuvant arthritis. Arch Biochem Biophys, 2015; 583: 150-157.

24. Bharti AC, Donato N, Singh S, Aggarwal BB. Curcumin (diferuloylmethane) down-regulates the constitutive activation of nuclear factor-kappa $B$ and IkappaBalpha kinase in human multiple myeloma cells, leading to suppression of proliferation and induction of apoptosis. Blood, 2003; 101(3): 1053-1062.

25. Kang $\mathrm{CH}$, Choi YH, Moon SK, Kim WJ, Kim GY. Quercetin inhibits lipopolysaccharide-induced nitric oxide production in BV2 microglial cells by suppressing the NF-kappaB pathway and activating the Nrf2dependent HO-1 pathway. Int Immunopharmacol, 2013; 17(3): 808-813 